\title{
Geology hits rich vein as South Africa boosts science spending
}

\begin{abstract}
Cape Town. The South African government is to increase its spending on science by 9 per cent in the financial year 1996-97, in line with the overall increase in government spending, and two percentage points above inflation. In a novel move, 7 per cent of this money has been reserved for research projects aimed at prioritized objectives.

The total budgets for the seven research councils, announced last month as part of the government's general spending plans for next year, amount to $R 1,002$ million (US\$250 million). Almost three-fifths will go to the two largest councils, the Council for Scientific and Industrial Research and the Agricultural Research Council, which both spend all of their funds on in-house research.
\end{abstract}

In terms of individual disciplines, geology will receive a major boost, reflecting the economic importance of the mining industry, with significant increases to the Councils for Geosciences (up 29.7 per cent to R60 million) and Minerals Technology (up 16.2 per cent to $R 73$ million). The Medical Research Council will receive an increase of 15.5 per cent, although its total will still be only $\mathrm{R58}$ million.

The main research funding agency, the Foundation for Research Development, will suffer a slight drop of one per cent in its money from the science vote, to R86 million. But this will be compensated for by an extra R16 million from separate Reconstruction and Development Programme (RDP) funds earmarked for centres of excellence at universities, technikons and museums.

The two national astronomical facilities, the South African Astronomical Observatory and the Hartebeeshoek RadioAstronomical Observatory, have both been given major increases of 23.4 and 22 per cent respectively in recognition of their important research contributions. The National Accelerator Centre, which has come in for criticism in recent years over its high operating costs, will suffer a small decrease, although its budget, at $\mathbf{R 3 8}$ million, still represents more than twice that of the observatories combined.

In line with the government's desire to emphasize strategic objectives, 7 per cent of this year's budget was reallocated on the basis of the recommendations of a panel of representatives from the private sector, civil service departments, universities and trade unions. The panel was chaired by Roger Jardine, director-general of the Department of Arts, Culture, Science and Technology. Council presidents made presentations to the panel to justify their bids in terms of how their research activities coincided with RDP priorities.

Michael Cherry

\section{Brazilian researcher protests against 'plagiarism' fine}

São Paulo. A Brazilian researcher has been told by an appeals tribunal that he must pay a fine of $\mathrm{R} \$ 50,000$ (US\$50,000) to a colleague for what she claims to be plagiarism of her work, which she had discussed widely at scientific conferences but only published belatedly.

Carlos Augusto Pereira, a senior researcher at the Instituto Butantan in São Paulo, was first accused in 1991 by Yeda Lopes Nogueira, a researcher at the Instituto Adolfo Lutz, of plagiarizing her research on the cytopathic effects of the rabies virus in a McCoy cell line.

After Nogueira's accusations had been upheld by a court in 1994, Pereira's lawyers filed a counterclaim in the São Paulo state appeals tribunal, arguing that what Nogueira called plagiarism is standard practice among scientists. But he lost again, with all three tribunal judges voting against him.

Pereira can still appeal to the supreme court, but the unanimous tribunal verdict makes it hard for him to prove his innocence. "This decision puts Brazil out of line with the rest of world," says João Luís Macedo, one of Pereira's lawyers. "If someone in China wants to carry out research on something discovered here, would he need a permit to do so?", he asks, claiming that such a requirement would paralyse science.

Nogueira, a former researcher at the São Paulo Instituto Pasteur, claims to be the first to have discovered the effects of the rabies virus in a McCoy cell line, announcing her achievement during a meeting in Rio de Janeiro in 1982. An abstract summarizing her discovery was published in the report of the meeting. Although she did not publish her results in a scientific journal, either in Brazil or abroad, she reported them to a number of scientific meetings. In 1989, however, she learnt that a team led by Pereira was working on the same subject.

Both researchers subsequently sent papers on the effects of rabies virus on McCoy cells to the Journal of Virological Methods. Nogueira's was rejected, and when she learned that Pereira's had been published, she took legal action. Her lawyer argued that Pereira's paper violates her intellectual property rights, as it does not mention her presentations at meetings. She accepts that scientists often investigate the work of others, including replicating original research. But, it is a "very different matter" if a scientist "usurps another's idea, and attributes the other's findings to himself".

In the paper's acknowledgements, Pereira's team "thanks Ms. I. Nogueira for helpful comments". His lawyers quote this as a proof Nogueira knew of his research, while Pereira points out that she even lectured at Butantan about her own work.

But her lawyer describes this acknowledgement as "another proof of bad faith", pointing out that it misspells her name. "He repeated the experiments, but he already knew my results," says Nogueira. "He added a few data, but nothing important."

The first guilty verdict against Pereira had argued that his 'plagiarism' had caused Nogueira "material and moral damage", and the new one confirms both the plagiarism and its moral impact. Nogueira claims that her scientific career was damaged, as she needed the research results to complete a master's degree.

Pereira is the more experienced researcher, having worked in Paris and Strasbourg for ten years before coming to the Butantan in 1985. He says that he has never denied Nogueira's contribution to the field "Our work is different, the contents are different, and we used different viral strains," he says. "Our basic conclusion is the same because as the same biological phenomenon was being studied," says Pereira, adding that he did not quote Nogueira in his paper because she had not published any papers he could refer to, apart from short abstracts in conference proceedings . Ricardo Bonalume Neto

\section{New grants for young Russian scientists}

Moscow. President Boris Yeltsin last week signed a decree establishing 100 grants, each worth 60 million roubles (US\$12,000), which he will award personally to talented young scientists. The decree also hands over to Russian colleges and universities federal property they have been leasing for the past 10 years or more, in addition to the land they previously owned.

The decree was announced in a speech to the University Rectors Congress in Moscow, in which Yeltsin described intellectuals as one of the "major forces" in the struggle for voters' hearts during the current presidential election campaign.

The decree also authorizes the cabinet to present the state Duma, Russia's lower parliament, with a bill fixing the pensions paid to college and university teachers at 80 per cent of their salary prior to retirement.

Earlier in the week, Yeltsin sent a message of congratulations to the Joint Institute for Nuclear Research (JINR) on the fortieth anniversary of its official foundation in 1956. "Russia is proud that this world science centre was built on its territory, and our state will always support it," wrote Yeltsin.

Carl Levitin 